Raymond Keeler and Bradley Lusk. Microbiome of Grand Canyon Caverns, a dry sulfuric karst cave in Arizona, supports diverse extremophilic bacterial and archaeal communities. Journal of Cave and Karst Studies, v. 83, no. 1, p. 44-56. DOI:10.4311/2019MB0126

\title{
MICROBIOME OF GRAND CANYON CAVERNS, A DRY SULFURIC KARST CAVE IN ARIZONA, SUPPORTS DIVERSE EXTREMOPHILIC BACTERIAL AND ARCHAEAL COMMUNITIES
}

\author{
Raymond Keeler ${ }^{1}$ and Bradley Lusk ${ }^{2, C}$
}

\begin{abstract}
We analyzed the microbial community of multicolored speleosol deposits found in Grand Canyon Caverns, a dry sulfuric karst cave in northwest Arizona, USA. Underground cave and karst systems harbor a great range of microbial diversity; however, the inhabitants of dry sulfuric karst caves, including extremophiles, remain poorly understood. Understanding the microbial communities inhabiting cave and karst systems is essential to provide information on the multidirectional feedback between biology and geology, to elucidate the role of microbial biogeochemical processes on cave formation, and potentially aid in the development of biotechnology and pharmaceuticals. Based on the V4 region of the 16S rRNA gene, the microbial community was determined to consist of 2207 operational taxonomic units (OTUs) using species-level annotations, representing 55 phyla. The five most abundant Bacteria were Actinobacteria $51.3 \pm 35.4 \%$, Proteobacteria $12.6 \pm 9.5 \%$, Firmicutes $9.8 \pm 7.3 \%$, Bacteroidetes $8.3 \pm 5.9 \%$, and Cyanobacteria $7.1 \pm 7.3 \%$. The relative abundance of Archaea represented $1.1 \pm 0.9 \%$ of all samples and $0.2 \pm 0.04 \%$ of samples were unassigned. Elemental analysis found that the composition of the rock varied by sample and that calcium (6200 $\pm 3494 \mathrm{ppm})$, iron (1141 $\pm 1066 \mathrm{ppm})$, magnesium $(25 \pm 17 \mathrm{ppm})$, and phosphorous (37 $\pm 33 \mathrm{ppm})$ were the most prevalent elements detected across all samples. Furthermore, carbon, hydrogen, and nitrogen were found to compose $4.7 \pm 4.9 \%, 0.3 \pm 0.4 \%$, and $0.1 \pm 0.1 \%$ of samples, respectively. Finally, Raman spectra compared to the RRUFF Project database using CrystalSleuth found that the mineral composition of the speleosol consisted of calcite, hematite, paraspurrite, quartz, and trattnerite. These data suggest that dry sulfuric karst caves can harbor robust microbial communities under oligotrophic, endolithic, and troglophilic conditions.
\end{abstract}

\section{INTRODUCTION}

Microorganisms are the principle components of the formation of the Earth's atmosphere, hydrosphere, and surface, and play a central role in karst cave formation and the cycling of organic and inorganic nutrients. For example, hydrogen sulfide-producing microbes can contribute to the formation of sulfuric karst caves in aqueous environments in a process called sulfuric acid speleogenesis (Engel et al., 2004). During sulfuric acid speleogenesis, limestone dissolves and hypogenic karst emerges as a result of artesian flow (Klimchouk et al., 2000). (An overview of this process is provided in Equations S1-S3.) As the limestone loses mass, microbial and chemical processes collectively drive a pedogenic erosion process that forms a bedrock-facing punk rock layer (Hill, 1987) and a cave-passage-facing oxide layer (Spilde et al., 2006). This process results in the formation of corrosion residues, or ferromanganese deposits (FMD), called speleosol (Spilde et al., 2009). The iron and manganese-rich composition of the oxide layers in speleosol is the result of microbial interactions with the minerals at the interface of the bedrock, punk rock, and oxide layer (Spilde et al., 2006; 2009).

Extremophiles are microorganisms that survive under conditions that are inhospitable to most life on Earth and are expected to be discovered in dry sulfuric karst caves given that the conditions are oligotrophic (limited access to essential nutrients), endolithic (ability to grow within rock or mineral pores) (Wierzchos et al., 2011), xerophilic (limited access to water) (Forbes, 1998; Lebre et al., 2017), and troglophilic (ability to grow within caves). Elucidating microbial life inhabiting extremophilic subterranean zones, including cave and karst systems, has many benefits. For example, it expands our concept of hospitable zones when searching for astrobiological life on other planets (Northup et al., 2011; Wierzchos et al., 2011; Lusk et al., 2019a). Next, the discovery of new microorganisms and genes from caves has led to the development of antibiotics and antifungals that may suppress the spread of diseases, including white-nose syndrome (WNS) in bats (Blehert et al., 2009; Hamm et al., 2017). Lastly, finding microbes that interact with metals and ores will assist in the discovery of biocatalysts, which can be used to interface living cells with materials for the production of biotechnology, including microbial electrochemical cells (Eddie et al., 2016; Lusk et al., 2018a; Sun et al., 2018).

Understanding the fundamental interactions of abiotic materials with biotic life, including microorganisms that are able to reduce and oxidize materials to produce or dissolve solid metals and ores, will enhance our understanding of the biogeochemical processes that shape the Earth (Eddie et al., 2016; Lusk et al., 2018a; 2019a; Sun et al., 2018). Spe-

${ }^{1}$ Central Arizona Grotto of the National Speleological Society, Phoenix, AZ, United States of America.

${ }^{2}$ ScienceTheEarth, Mesa, AZ, United States of America.

CCorresponding author: ScienceTheEarth@gmail.com, ORCID: 0000-0002-3094-805X. 
leosols in caves, for example, provide an ideal habitat for investigating robust microbial communities associated with geomicrobially-mediated sulfuric acid speleogenesis. Given the variety of regions and conditions in which geomicrobially-mediated sulfuric acid speleogenesis occurs (Engel et al., 2004), a robust and systematic study of microorganisms residing in caves is essential to develop a comprehensive explanation of this phenomenon.

Grand Canyon Caverns (GCC) is a commercial dry cave in northwest Arizona, USA that was formed via sulfuric acid speleogenesis. In February 2013, approximately 100 meters of steeply up-trending new passages and rooms were discovered containing multicolored corrosion residues composed of punk rock (Hill, 1987) and containing an oxide layer, also called speleosol (Spilde et al., 2006; 2009). Similar deposits in Lechuguilla and Spider Caves located in the Guadalupe Mountains of New Mexico were previously observed to harbor microbial life (Northup et al., 2003; Spilde et al., 2006). The formations discovered in GCC were kept isolated from tourists for the purpose of conducting research on their microbial inhabitants. To assess the diversity of microorganisms, 14 dry samples from three separate areas were collected from sections throughout the cave that had minimal perturbation from human activity (sampling locations shown in Fig. 1). Samples were analyzed for their elemental, mineralogical, and microbial composition.

\section{MATERIALS AND METHODS}

\section{Cave Description and Overview}

GCC is a commercial dry sulfuric karst cave in northwest Arizona, USA $\left(35^{\circ} 31^{\prime} 41.9^{\prime \prime} \mathrm{N} 113^{\circ} 13^{\prime} 52.7^{\prime \prime} \mathrm{W}\right)$ that is located about 100 kilometers south of the southern rim of Grand Canyon National Park. The cave is positioned in the upper part of the Redwall limestone from the Late Devonian / Early Mississippian periods (Huddle and Dobrovolny, 1952) with a small, inactive volcano located five kilometers northwest. The Redwall limestone dates back to approximately $350 \mathrm{Ma}$ and is composed of $99.5 \%$ pure limestone (Gootee, 2014; 2019). During this period, the region was part of a shallow tropical sea in the equatorial continent of Laurentia (Price, 1999; Gootee, 2019). Presently, the cave has no known freestanding bodies of water and has an average relative humidity of $79.5 \%$ and temperature of $15{ }^{\circ} \mathrm{C}$. There are no indications of the presence of non-microbial life in the cave; however, there have not been surveys for non-microbial life in GCC.

A map of the cave, including sample collection locations, is shown in Figure 1. Annually, thousands of tourists visit GCC. At the time of sample collection, cave tours were limited to the main sections of GCC including the Chapel of Angels, the Halls of Gold, Snowball Palace, and the Mystery Chamber, and ceased at gates 1 and 2. Gates 1 and 2 were installed to limit access to newly-discovered areas of the cave for the purpose of mapping and conducting research. Due to the observation of multicolored speleosol deposits on the cave walls on top of the underlying limestone (Fig. 2), 14 samples were collected from Sugar Hill, below the ropes to Disappointment Dome, and Disappointment Dome. Since collecting samples, tourism has now extended to Sugar Hill and below the ropes to Disappointment Dome.

\section{Sample Collection}

Sterile Falcon tubes $(15 \mathrm{~mL})$ were used to store 14 samples ( $500 \mathrm{mg}$ each) that were collected in the cave. Each sample was collected by scraping the Falcon tube directly against the cave surface to collect solid surface deposits of
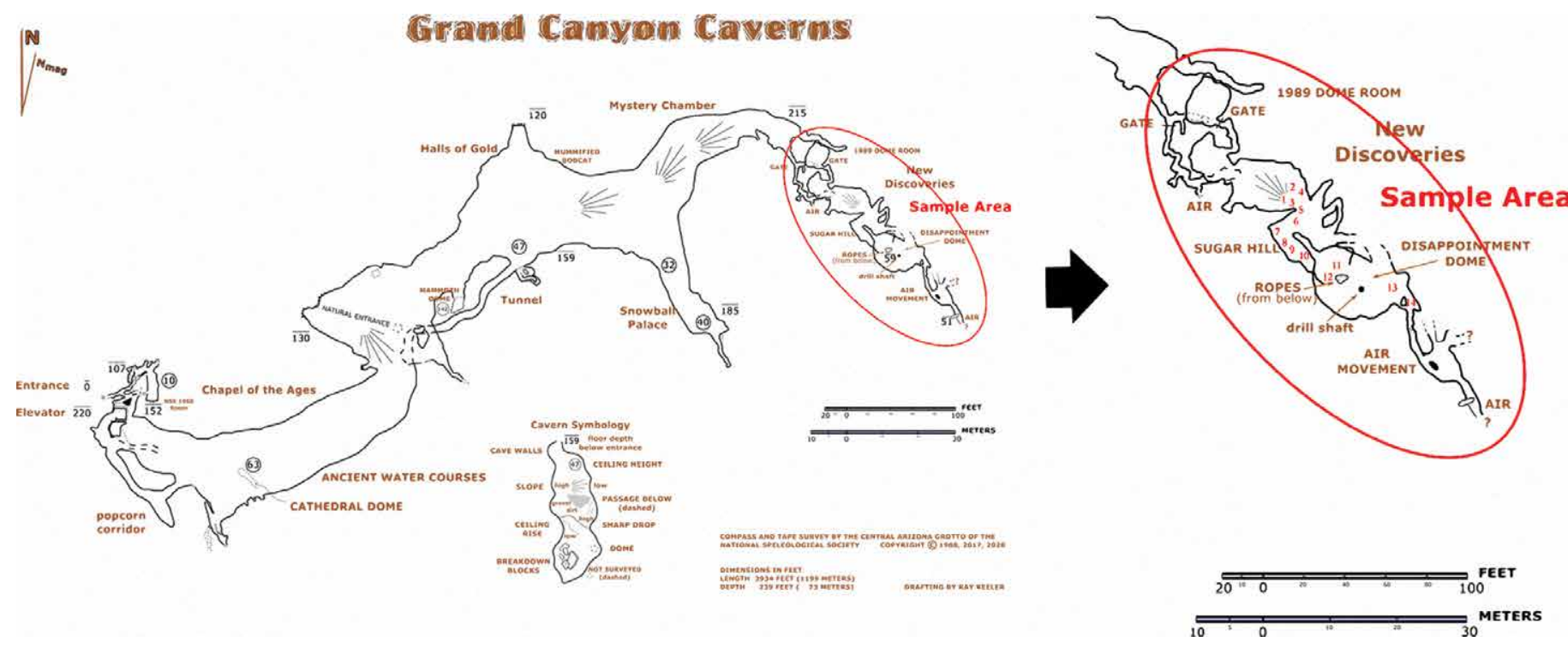

Figure 1: Cave map for Grand Canyon Caverns. Inset on right shows collection locations for 14 samples. The three major sampling locations were Sugar Hill, below the ropes to Disappointment Dome, and Disappointment Dome. At the time of collection, active tourism in the cave ceased at gates 1 and 2 . 
speleosol from the cave walls. After placing the lid on the Falcon tube, each tube was wrapped in aluminum foil, placed on icepacks, stored in an ice chest, and transported to a $-80{ }^{\circ} \mathrm{C}$ freezer. All samples were collected in the deep zone of the cave, at least $200 \mathrm{~m}$ from the nearest entrance with no surface visible light. Sample collection locations varied from a meter to several meters apart and are shown in the inset to Figure 1.

\section{Sample Identification via Raman Spectroscopy and CrystalSleuth}

The mineral composition of each rock sample was identified using a Renishaw via Reflex Micro-Raman confocal Raman Microscope (Renishaw, West Dundee, III., U.S.A.) equipped with a Leica 566066 N PLAN EPI $20 X / 0.4$ (Leica, Wetzlar, Germany) objective lens and two laser excitation sources: a near infrared diode laser source (300 mW) with an excitation wavelength of $785 \mathrm{~nm}$ and an Argon ion laser source $(25 \mathrm{~mW})$ with an excitation wavelength of $514 \mathrm{~nm}$. For spectra captured at $785 \mathrm{~nm}$, laser power was varied from 1-50\%, exposure time set to 1-3 seconds, and spectra were averaged over five accumulations. For spectra captured at $514 \mathrm{~nm}$, laser power was set to $100 \%$, exposure time set to one second, and spectra were averaged over twelve accumulations. For each sample, spectra at $785 \mathrm{~nm}$ and $514 \mathrm{~nm}$ were tak-

a

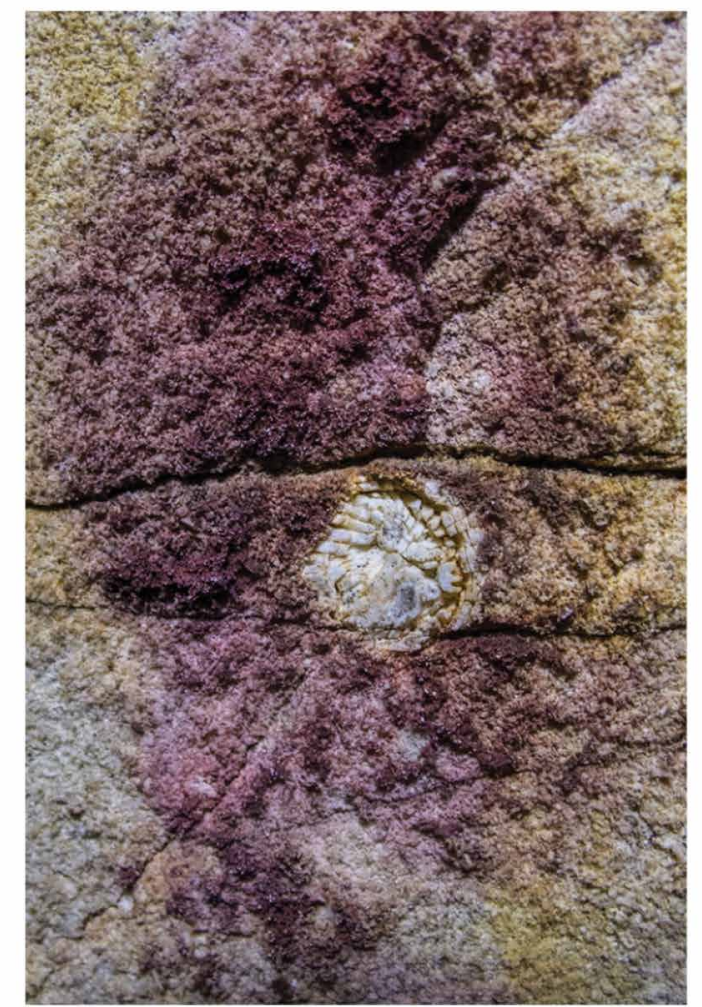

C

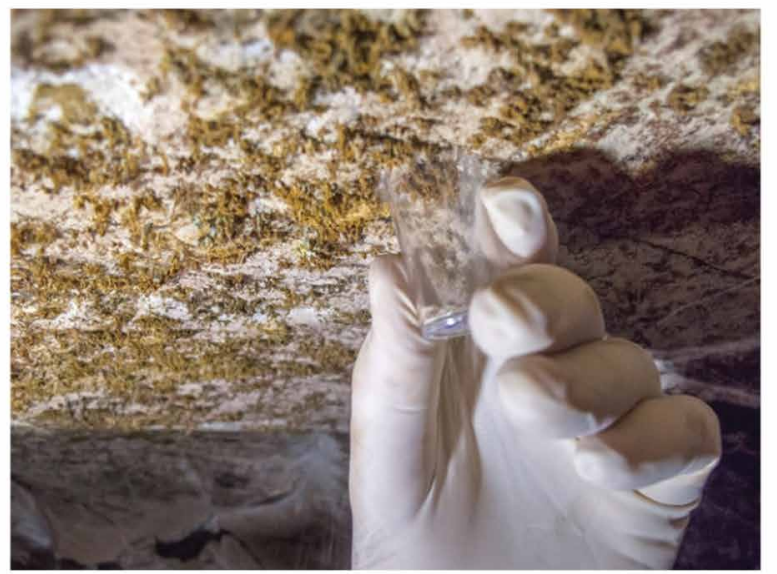

$\mathrm{b}$

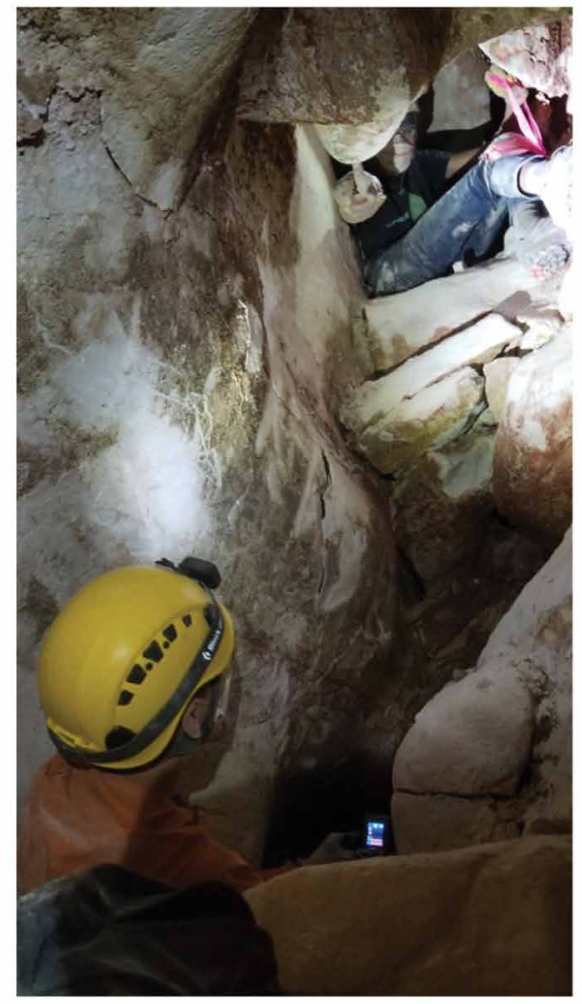

d

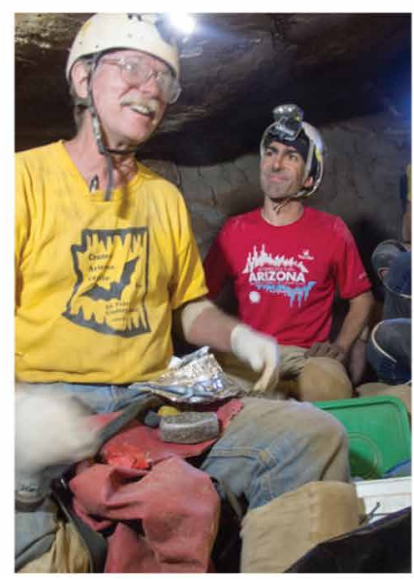

Figure 2: a) Multicolored, powdery speleosol deposit on the cave wall surrounding a Late Devonian/ Early Mississippian period rugose coral fossil (photo credit: Paul Jorgenson). b) Brown colored powdery speleosol deposit on cave wall with cavers shown for scale. c) Collecting a sample from a yellow colored speleosol deposit (photo credit: Paul Jorgenson). d) Co-authors Raymond Keeler and Bradley Lusk wrapping samples in foil and collecting video documentation of cave expedition (photo credit: Paul Jorgenson).

en at three different locations. After acquiring Raman spectra, light images were acquired under white light using the same objective lens. Spectra were compared to the RRUF Project database using the CrystalSleuth Application Version: May 19, 2008 (Laetsch and Downs, 2006). For identifying samples, background was subtracted, cosmic ray events (CRE) were removed, and a cutoff of $90 \%$ similarity was used to determine a match. Filtered spectra with corresponding light images can be found in Figure S2 GCC1-14.

\section{Digestion and Quantification of Elements}

Samples were digested (255.3 $\pm 6.2 \mathrm{mg}$ ) using a MARS 5 Microwave Digester (CEM Corporation, Matthews, N.C., U.S.A.). For the microwave process, each sample was weighed and 10 
$\mathrm{mL}$ of concentrated trace metal grade nitric acid was added. All sample tubes were heated to $180{ }^{\circ} \mathrm{C}$ in 5 minutes and held at $180{ }^{\circ} \mathrm{C}$ for 10 minutes in a $1600 \mathrm{~W}$ microwave. After heating, samples were cooled for 5 minutes. The elemental composition of samples was analyzed using a Thermo iCap 6300 inductively coupled plasma optical emission spectrometer (ICP-OES) (Thermo Fisher Scientific, Waltham, Mass., U.S.A.) with a duo plasma source. Samples were diluted at 1:10 with nano-pure water to acquire accurate measurements for the following metals: $\mathrm{Ag}, \mathrm{Al}, \mathrm{As}, \mathrm{B}, \mathrm{Ba}, \mathrm{Be}$, $\mathrm{Bi}, \mathrm{Cd}, \mathrm{Co}, \mathrm{Cr}, \mathrm{Cu}, \mathrm{K}, \mathrm{Li}, \mathrm{Mg}, \mathrm{Mn}, \mathrm{Mo}, \mathrm{Na}, \mathrm{Ni}, \mathrm{P}, \mathrm{Pb}, \mathrm{S}, \mathrm{Sb}, \mathrm{Se}, \mathrm{Si}, \mathrm{Sr}, \mathrm{Tl}, \mathrm{V}$, and $\mathrm{Zn}$. Due to the high concentration of $\mathrm{Ca}$ and $\mathrm{Fe}$, separate samples for these elements were diluted at 1:1000 with nano-pure water. Sample 5 did not contain enough mass for analysis using the ICP-OES.

For quantification of total C, H, and N, a Perkin Elmer PE 2400 Elemental Analyzer was used with $5.4 \pm 0.6 \mathrm{mg}$ per sample (https://cores.research.asu.edu/metals-environmental-and-terrestrial-analytical-laboratory/equipment/analytical-chn-elemental). Samples were flash combusted at $1760{ }^{\circ} \mathrm{C}$. Resulting gases were chemically scrubbed of the halogens (and of sulfur in the $\mathrm{CHN}$ mode) and were separated in a GC column. Detection was conducted by a thermal conductivity detector (TCD).

\section{Scanning Electron Microscopy (SEM) and Color Images}

Approximately $5 \mathrm{mg}$ from each of the 14 samples was fixed with $4 \%$ glutaraldehyde for $12 \mathrm{~h}$ at $4{ }^{\circ} \mathrm{C}$ and then washed and stored in $10 \mathrm{mM}$ PBS ( $\mathrm{pH} 7$ ) solution for $\sim 1 \mathrm{~h}$. Next, the samples were treated with $1 \%$ osmium tetroxide for 15 min, followed by graded ethanol series dehydration (50\%,70\%, 95\%, and 100\% for 5 min each), then critical point dried, and ultimately mounted on an aluminum stub. Samples were sputter-coated with Au/Pd alloy with a Technics Hummer II sputter coater. Imaging was conducted using a JEOL JSM6300 SEM at 15X - 95kX with an accelerating voltage of 15 kV. Color images of samples (Fig. 3) were taken with a Samsung Galaxy S7 under white light conditions.

\section{DNA Extraction and Library Preparation for 16S RRNA Sequencing}

DNA from the 14 samples was extracted using the PowerSoil DNA Isolation Kit (MO BIO, Carlsbad, Calif., U.S.A.) per the manufacturer's manual. DNA was released from cells via bead beating using PowerBead tubes (MO BIO, Carlsbad, Calif., U.S.A.). Amplicon sequencing of the V4 region of the $16 \mathrm{~S}$ rRNA gene was performed with the barcoded primer set $515 f / 806 r$ designed by Caporaso et al. (2012), following the protocol proposed by the Earth Microbiome Project (EMP https://earthmicrobiome.org/protocols-and-standards/16s/) for the library preparation. PCR amplifications for each sample were done in triplicate, then pooled and quantified by using Quant-iT PicoGreen dsDNA Assay Kit (Invitrogen, ThermoFisher Scientific, Waltham, Mass., U.S.A.). A total of $240 \mathrm{ng}$ of DNA per sample was pooled and then cleaned using QIA quick PCR purification kit (QIAGEN, Valencia, CA, USA). The PCR pool was quantified by Illumina Library Quantification Kit ABI Prism (Kapa Biosystems, Wilmington, MA, USA). The DNA pool was determined and diluted to a final concentration of $4 \mathrm{nM}$, then denatured and diluted to a final concentration of $4 \mathrm{pM}$ with $30 \%$ PhiX. Finally, the DNA library was loaded in the MiSeq Illumina Sequencer (Illumina, San Diego, CA, USA) using the chemistry version $2(2 \times 150$ paired-end) and following manufacturer directions. All samples were sequenced in the Microbiome Analysis Laboratory at Arizona State University (Tempe, Ariz., U.S.A.).
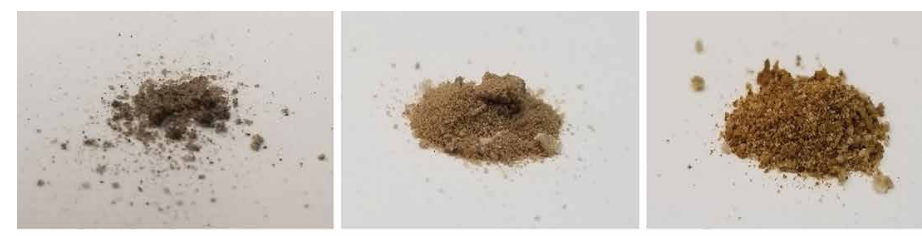

$\mathrm{GCCl}$

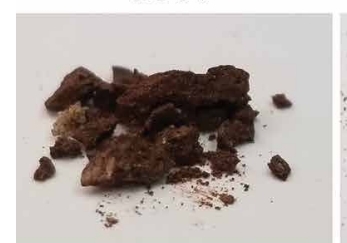

GCC2

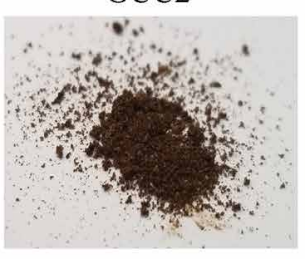

GCC7

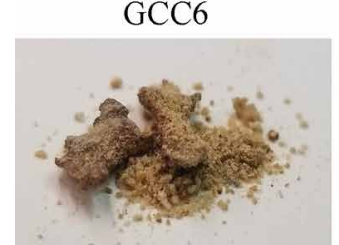

GCC11

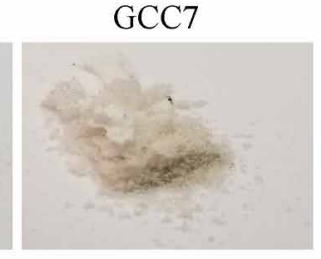

GCC12
GCC3

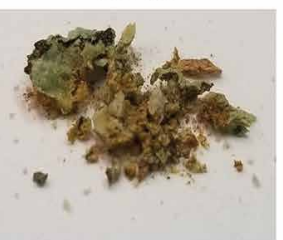

GCC8

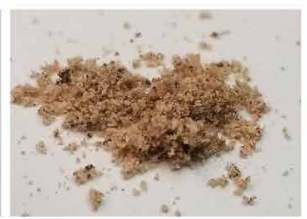

GCC13

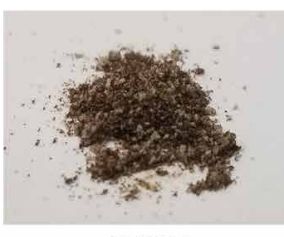

GCC4

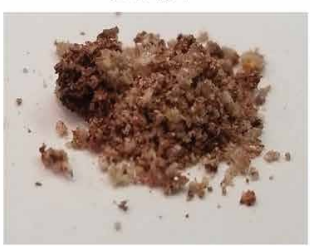

GCC9

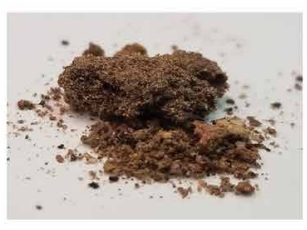

GCC14

Figure 3: Macroscopic images of samples 1-14

\section{Determination of Microbial Taxonomy}

The analysis of the 16S rRNA gene sequences was performed using the Quantitative Insights into Microbial Ecology 2 software package (QIIME2, version 2018.4) (Bolyen et al., 2019). Sequences were open reference clustered into Operational Taxonomic Units (OTUs) against the Silva-132 
database (Quast et al., 2013) using an identity threshold of $97 \%$ with the vsearch algorithm (Rideout et al., 2014). After the alignment of the sequences, the OTU table was constructed and then filtered for the removal of singletons, and chimeras and borderline chimeras using vsearch uchime-denovo (Edgar et al., 2011). Eukaryotic homologues were also removed. The OTU table was rarefied to the minimum number of sequences obtained among the samples (GCC 12 with 44,297 sequences) and an alpha diversity rarefaction table was constructed using 10 iterations for each sample data point. Finally, the taxonomy was assigned to OTUs using a Scikit-learn naïve-Bayes taxonomy classifier against the Silva_132_97_16s OTUs reference sequences (Pedregosa et al., 2018), with counts for classified OTUs at all phylogenetic levels (Table S1), and an Excel file with all observed OTUs (Table S2).

\section{RESULTS AND DISCUSSION}

This research study assesses the mineralogical and microbial diversity of multicolored speleosol deposits found in GCC. These deposits ranged from several centimeters to several meters spanning entire walls of the cave. Similar formations have been observed in Lechuguilla and Spider Caves in New Mexico, United States (Northup et al., 2003), the Cave of Altamira in Spain (Jurado et al., 2007), Roraima Sur Cave in Venezuela (Barton et al., 2014), and Asperge Cave in France (Tisato et al., 2015), Figure 2a-d shows examples of formations from which samples were collected and the acquisition of samples within the cave. As shown in Figure 2a, some multicolored formations were found surrounding fossils of rugose coral from the Late Devonian / Early Mississippian period (Huddle and Dobrovolny, 1952; Pedder and Murphy, 2004; Denayer et al., 2012). Figure $2 b$ shows a deposit spanning approximately three meters of a wall with surveying cavers to add scale. Figure $2 c$ shows sample collection directly from the cave walls and Figure $2 \mathrm{~d}$ shows cavers wrapping samples into foil and documenting the sample locations.

Speleosol samples collected at 14 sites in the cave varied in color and consistency (Fig. 3). Raman spectroscopy was used to determine the mineral contents of each sample (Table 1) by comparing spectra to the RRUFF ${ }^{\mathrm{TM}}$ Project database using the CrystalSleuth Application Version: May 19, 2008 (Laetsch and Downs, 2006). The samples were primarily composed of calcite, hematite, paraspurrite, quartz, and trattnerite. A detailed description of each sample can be found in the supplemental information and filtered spectra with light microscopy images in Figure S2 GCC1-14.

An elemental analysis was done on GCC samples (Tables 2a-b). The composition of the speleosols varied by sample with calcium $(6200 \pm 3494 \mathrm{ppm})$, iron (1141 $\pm 1066 \mathrm{ppm})$, magnesium $(25 \pm 17 \mathrm{ppm})$, and phosphorous $(37 \pm 33 \mathrm{ppm})$ the most prevalent elements detect-

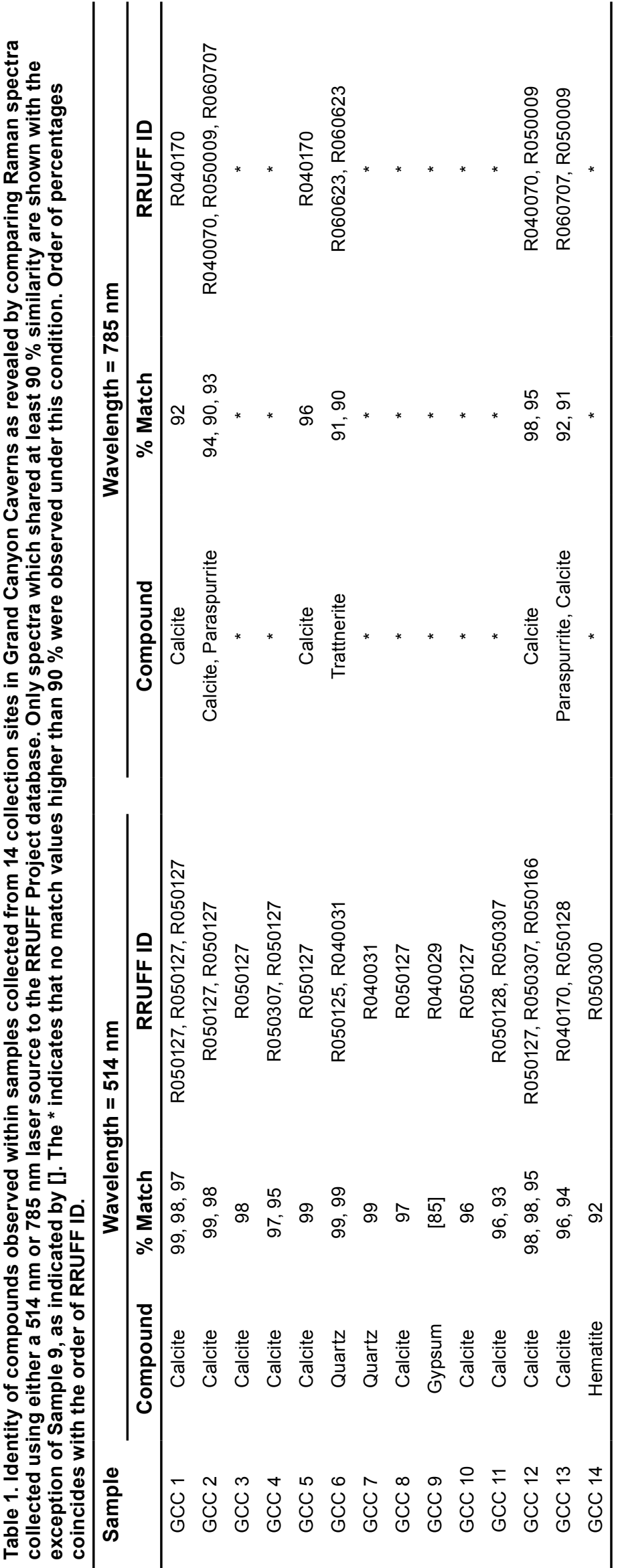


ed across all samples. Aluminum ( $49 \pm 57 \mathrm{ppm}$ ) was observed in seven samples, manganese ( $43 \pm 58 \mathrm{ppm})$ in 12 samples, potassium (93 $\pm 88 \mathrm{ppm})$ in 13 samples, and silicon ( $5 \pm 2)$, sodium ( $5 \pm 5)$, and zinc $(23 \pm 62)$ in all samples. Total carbon, hydrogen, and nitrogen made up $4.7 \pm 4.9 \%, 0.3 \pm 0.4 \%$, and $0.1 \pm 0.1 \%$ of samples, respectively (Table 3 ).

Due to the mixed nature of each sample, it is possible that minerals present in small quantities are difficult to observe using Raman spectroscopy since they are masked by more ubiquitous compounds. Nevertheless, the prevalence of $\mathrm{Ca}, \mathrm{C}, \mathrm{Fe}, \mathrm{Mg}, \mathrm{Na}, \mathrm{P}, \mathrm{Si}$, and $\mathrm{Zn}$ are likely the result of the hematite, paraspurrite, trattnerite, and limestone that contributes to the composition of the punk rock and underlying cave walls. The high Fe content likely is due to the accumulation of iron oxides resulting from microbial-induced enrichment in the oxide layer of the speleosol (Spilde et al., 2009), although auto-oxidation of ferrous iron at neutral $\mathrm{pH}$ may also play a role (Emerson and Moyer, 1997). The presence of Al, Ca, Fe, K, $\mathrm{Mg}, \mathrm{Mn}$, and Si corroborates previous literature documenting microbial interactions with minerals in ferromanganese deposits (FMD), or speleosol, including todorokite, lepidocrocite, goethite, illite, and hematite (Northup et al., 2003; Spilde et al., 2005).

Scanning electron microscopy (SEM) on each of the samples (Fig. 4) revealed the presence of diverse microbial morphologies associated with the speleosol. Diverse biological communities have also been observed and associated with cave mineralogy in other cave sites (Cunningham et al., 1995; Boston et al., 2009; Dhami et al., 2018). Although SEM cannot be used to identify specific bacteria, GCC $3,4,7,10$, and 14 show the presence of cells with similar morphology to those observed in extremophilic and mesophilic dissimilatory metal reducing bacteria that metabolize metal oxides (Spilde et al., 2005; El-Naggar et al., 2010; Parameswaran et al., 2013; Lusk et al., 2015a,b; 2016; 2018a; 2019a; Wang et al., 2019).

The GCC microbial community consisted of 2207 operational taxonomic units (OTUs) according to species-level annotations, representing 55 phyla. (See Table S1 for sample overview and Table S2 for taxonomy assignments of all OTUs.) As shown in Figure 5, of the 55 phyla found among all samples, the five most abundant bacterial phyla were Actinobacteria $51.3 \pm 35.4 \%$, Proteobacteria $12.6 \pm 9.5$ $\%$, Firmicutes $9.8 \pm 7.3 \%$, Bacteroidetes $8.3 \pm 5.9 \%$, and Cyanobacteria $7.1 \pm 7.3 \%$, while the relative abundance of Archaea represented $1.1 \pm 0.9 \%$ of all samples and $0.2 \pm 0.04 \%$ of sequences were unassigned. The rarefaction curve for $\alpha$-diversity in 14 samples (Fig. S1) shows a slope nearing zero for all samples except GCC2, suggesting the data shown represent the true diversity of the samples with the exception of GCC2, which may have greater diversity.

Gram-positive bacteria from the phylum Actinobacteria, the most prevalent phylum found in GCC, have been reported to generate several bioactive compounds, produce two-thirds of all clinically used naturally-derived antibiotics, and have been indicated as likely candidates for the development of new antibiotics and antifungals (Nimaichand et al., 2012; Barka et al., 2016; Maciejewska et al., 2016; Rangseekaew and Pathom-Aree, 2019). For example, the genera Amycolatopsis (1.6 $\pm 2.3 \%$ ) and Pseudonocardia (16.2 $\pm 17.0 \%$ ) were present in all samples and previous studies have indicated that these genera may have antifungal properties (Sen et al., 2009). Furthermore, the Streptomyces genus, a common in-

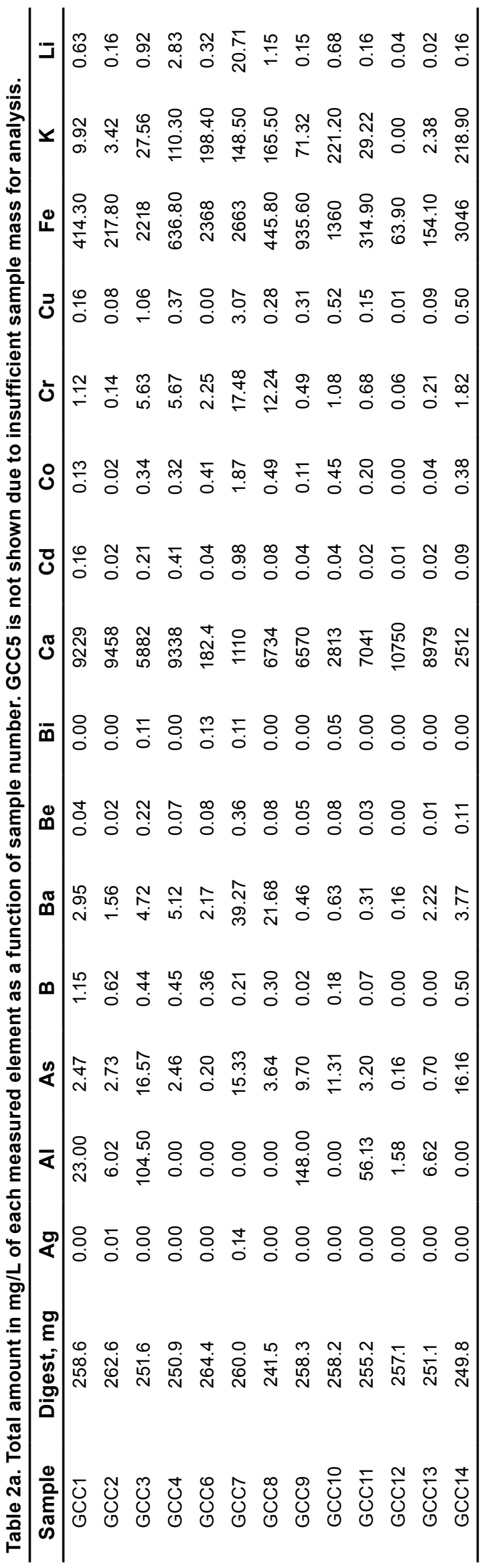




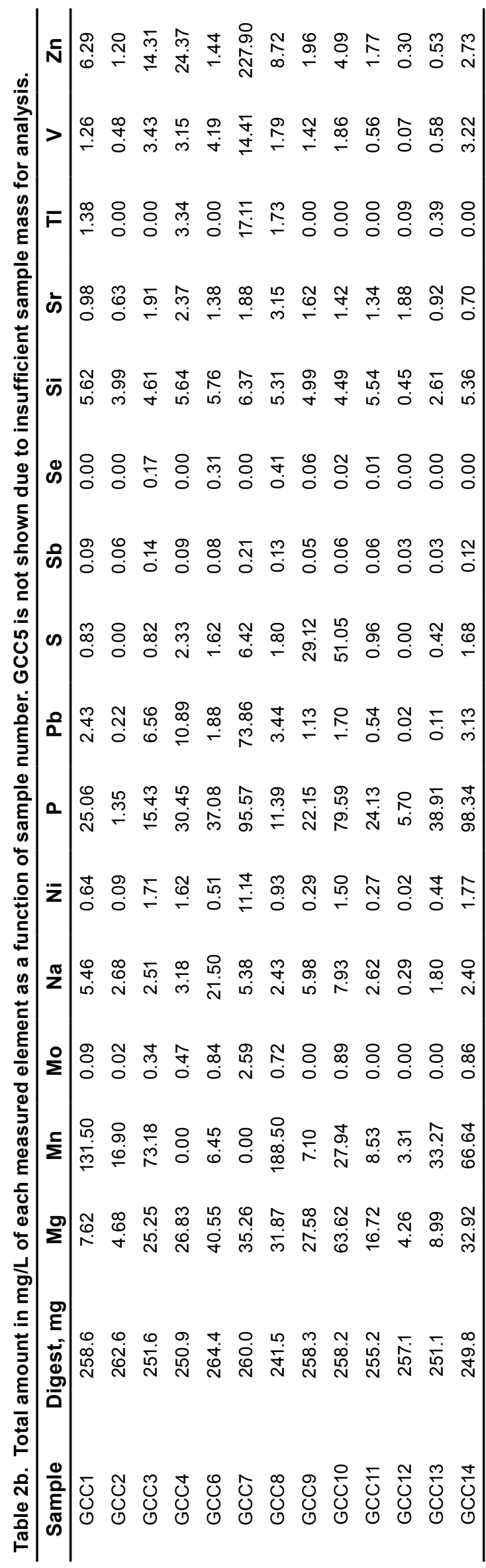

habitant of limestone caves (Nimaichand et al., 2012; Také et al., 2018) and responsible for most of the commercially-available naturally-derived antibiotics on the market (Bérdy, 2005; Barka et al., 2016), composed $2.4 \pm 3.0 \%$ of sequences observed across all samples. Novel Streptomyces species discovered in other caves located in the western United States have shown antifungal effects on Pseudogymnoascus destructans, a fungus that causes white-nose syndrome (WNS) in bats (Blehert et al., 2009; Hamm et al., 2017). Lastly, xerophilic members of the Actinobacteria phylum including the genera Geodermatophilus and Modestobacter from the Geodermatophilaceae family (Montero-Calasanz et al., 2012; 2013), the Rubrobacteridae family (Bull and Asenjo, 2013), and the Streptomyces genus (Kurapova et al., 2012; Mohammadipanah and Wink, 2016) account for a relative abundance of $2.7 \pm 2.8 \%$ across all samples observed from the cave.

Cyanobacteria of the family Phormidiaceae $(0.5 \pm 0.7 \%)$ were observed in all GCC samples. They were previously observed dwelling in troglophilic conditions within caves, including Carlsbad Cavern (Behrendt et al., 2019), and are capable of surviving for prolonged periods of time in complete darkness (Hader and Poff, 1982; Montechiaro and Giordano, 2006). Photosynthetic bacteria may be able to persist in the deep zones of the cave that harbor minimal or no surface visible light by having chlorophylls that absorb near infrared radiation (NIR) that is reflected across the limestone walls of the cave (Behrendt et al., 2019).

In addition, bacteria from the Porphyromonadaceae family in the phylum Bacteroidetes are commonly associated with acid mine drainage and sulfur reducing microbial communities (Gaidos et al., 2009; Bijmans et al., 2010) were present in nine of the 14 samples $(0.14 \pm 0.14 \%)$. Finally, bacteria from the Arcobacter genus in the class Epsilonproteobacteria were observed in all samples $(1.0 \pm 0.8$ $\%)$; previous research has indicated that these microorganisms are autotrophic and produce globular or filamentous sulfur as a metabolic end product (Wirsen et al., 2002).

Nitrogen, an essential component of amino acids and nucleotides, was found in concentrations of $0.1 \pm 0.1 \%$, and was not de-

Table 3. Total amount, in \% of carbon, hydrogen, and nitrogen as a function of sample number.

\begin{tabular}{ccccc}
\hline Sample & Digest, $\mathbf{m g}$ & Carbon, $\%$ & Hydrogen, $\%$ & Nitrogen, $\%$ \\
\hline GCC1 & 5.06 & 11.50 & 0.03 & 0.09 \\
GCC2 & 5.03 & 11.89 & 0.00 & 0.05 \\
GCC3 & 4.96 & 7.49 & 1.33 & 0.08 \\
GCC4 & 5.00 & 8.68 & 0.04 & 0.08 \\
GCC5 & 4.95 & 2.36 & 0.32 & 0.05 \\
GCC6 & 6.63 & 0.25 & 0.35 & 0.05 \\
GCC7 & 6.03 & 0.96 & 0.79 & 0.08 \\
GCC8 & 5.95 & 9.19 & 0.05 & 0.15 \\
GCC9 & 5.88 & 9.19 & 0.05 & 0.15 \\
GCC10 & 6.25 & 0.59 & 0.58 & 0.05 \\
GCC11 & 5.35 & 0.21 & 0.12 & 0.00 \\
GCC12 & 5.45 & 0.14 & 0.02 & 0.00 \\
GCC13 & 4.65 & 0.21 & 0.00 & 0.00 \\
GCC14 & 4.44 & 0.34 & 0.09 & 0.00 \\
\hline
\end{tabular}



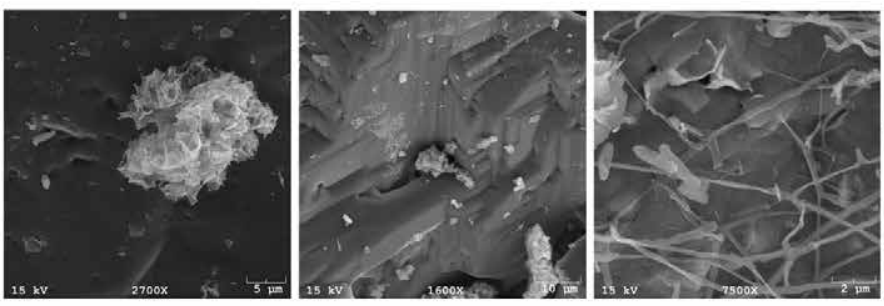

GCC2
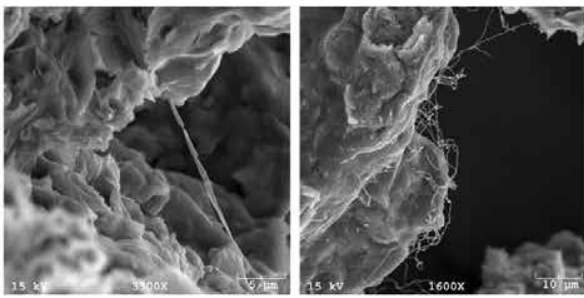

GCC7

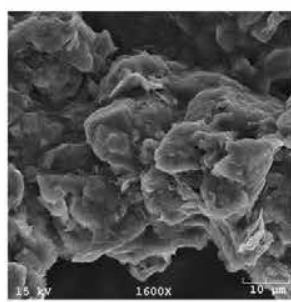

GCC11

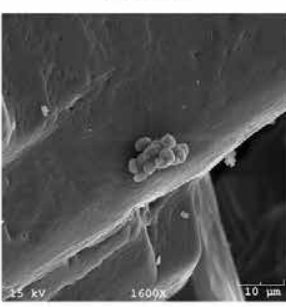

GCC12
GCC3

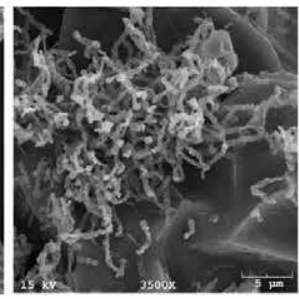

GCC8

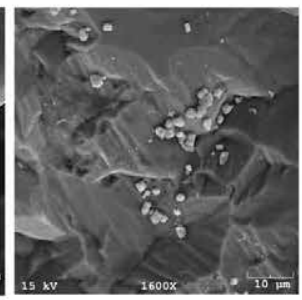

GCC13

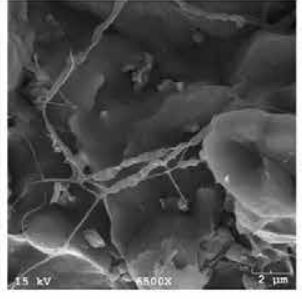

GCC4

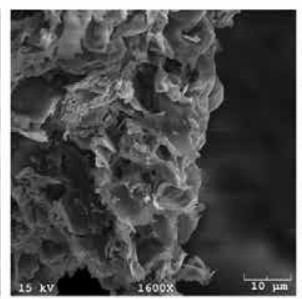

GCC9

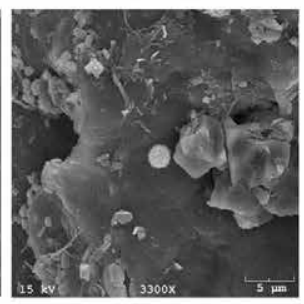

GCC14

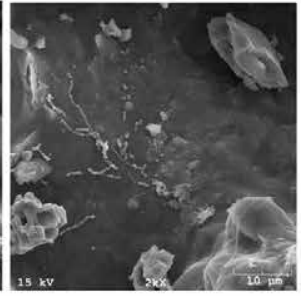

GCC5

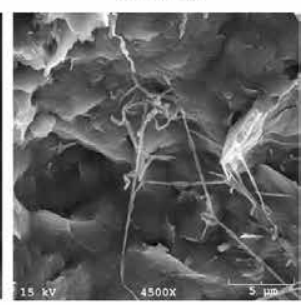

GCC10

Figure 4: Scanning electron images of Samples 1-14. SEM images contain examples of multiple morphologies from diverse microorganisms. Images are at following magnifications: GCC1 2700x, GCC2 1600x, GCC3 7500x, GCC4 6500x, GCC5 2000x, GCC6 3300x, GCC7 1600x, GCC8 3500x, GCC9 1600x, GCC10 4500x, GCC11 1600x, GCC12 1600x, GCC13 1600x, GCC14 1600x.

et al., 2018) and Burkholderiales (Rosenblueth et al., 2018) orders suggests that nitrogen fixation microbial communities occupying GCC (Northup et al., 2003; Wagner, 2011); however, this hypothesi

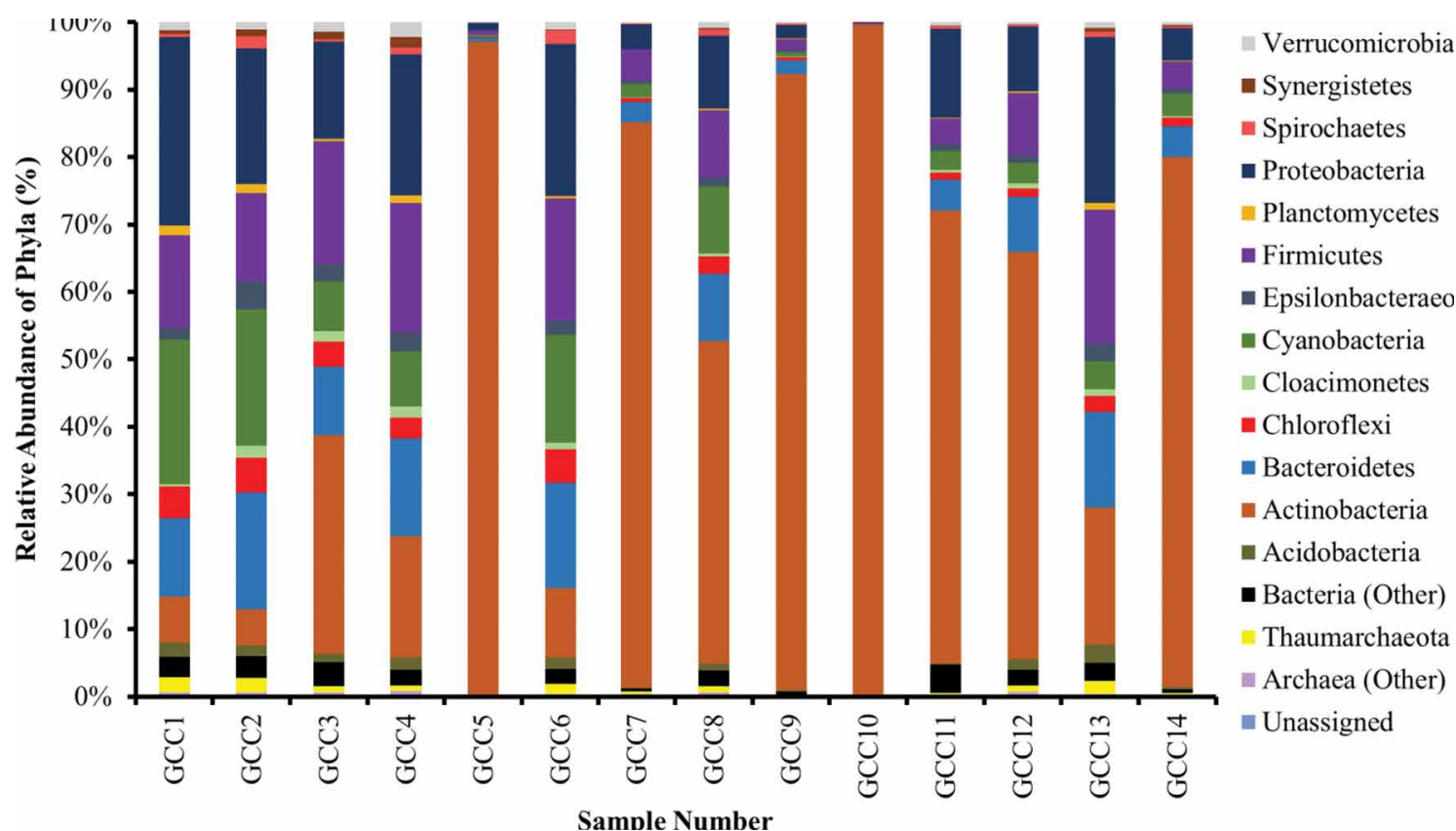

Figure 5: Relative abundance of bacterial and archaeal taxonomy at phylum level. All phyla with at least $\sim 1 \%$ relative abundance in one or more samples are listed. Remaining phyla within the Bacteria kingdom are represented in the Bacteria (Other) category. Remaining phyla within the Archaeal kingdom are represented in the Archaea (Other) category. Unassigned sequences $(0.2 \pm 0.04 \%)$ are also represented. tected in samples GCC 11, 12, 13, or 14 (Table 3). This concentration of $\mathrm{N}$ is comparable to those observed in other caves containing nitrogen-fixing bacteria (Northup et al., 2003). The prevalence of diazotrophs $\pm 1.7 \%$ ) including methanogenic Euyarchaeota (Murray and Zinder, 1984; Leigh, 2000; Bae et al., 2018), bacteria of the Clostridium genus (Chen et al., 2001), Frankiacea from the Actinobacteria phylum (Santi et al., 2013), and Rhizobia from the Rhizobiales (Diaz-Herraiz et al., 2014; Garrido-Oter on may play a role in esis requires further investigation.

In addition, previously characterized microorganisms that are able to reduce and oxidize materials to produce or dissolve solid metals and ores were present in all samples (3.8 \pm 2.9 $\%)$. Observed genera include: Geothrix (Coates et al., 1999), Pedomicrobium (Northup et al., 2003), Thiobacillus (Provencio et al., 2001), Geobacter (Bond and Lovley, 2002), Arcobacter (Wirsen et al., 2002), Marinobacter (Bo- 
nis and Gralnik, 2015), Desulfovibrio (Payne et al., 2002), Desulfuromonas (Roden and Lovley 1993), Pseudomonas (Caspi et al., 1998), and Shewanella (El-Naggar et al., 2010), and the families Desulfobulbaceae (Pfeffer et al., 2012) and Rhodocyclaceae (Zhou et al., 2016). These dissimilatory metal-reducing and/or oxidizing bacteria are able to use Fe (observed in all samples at $1141 \pm 1066$ ppm) or Mn (observed in samples GCC 1-3, 6, and 8-14 at $43 \pm 58$ ppm) as an electron source or as a terminal electron acceptor, as shown in Equations S4-S7.

\section{Conclusion and Future Research}

The formation of caves and karst systems relies on a complex interplay between abiotic and biotic geochemical activity (Hose et al., 2000; Kappler et al., 2005; Barton and Northup, 2007; Boston et al., 2009). In many cases, microbial communities contain the metabolic capacity to oxidize and reduce surrounding metallic ores, which greatly influences the structure and mineralogy of the cave environment (Lovley, 1993; Northup et al., 2003; Spilde et al., 2006, 2009). The microbial community data presented in this study suggests that Grand Canyon Caverns (GCC), a dry sulfuric karst cave, harbors robust extremophilic, oligotrophic, endolithic, xerotolerant, and troglophilic microbial life within multicolored speleosol deposits found overlying its limestone walls. However, while sequencing results indicate that most of the microbial diversity within the cave speleosol has been accounted for (Fig. S1), Archaeal diversity may not be fully represented given the bias the $515 \mathrm{f}-806 \mathrm{r}$ bacterial/archaeal primer pair has against Crenarchaeota/Thaumarchaeota (Hugerth, 2014), environmental Archaea, and certain clades of Bacteria (Morris et al., 2002).

Based on the roles microbes observed in GCC play in similar caves, they are hypothesized to utilize a large repertoire of metabolic pathways including nitrogen fixation (Northup et al., 2003; Wagner, 2011), chemolithoautrophic carbon fixation (Ramos, 2003), and dissimilatory metal reduction and oxidation (Angert et al., 1998; Povencio and Polyak, 2001; Northup et al., 2003; Macalady et al., 2006) that enables them to survive using a diverse set of electron donors and acceptors, including solid ores. Microbial reduction and oxidation of surrounding minerals and the corresponding shift in the elemental composition and oxidation states of these minerals may explain the diversity of colors observed in the cave speleosol and in the collected samples (Fig. 2 and 3). However, future studies to observe the proteomic, metagenomic, and transcriptomic profiles of the communities will offer more insight into their functional and metabolic roles.

Furthermore, finding correlations between microbial communities, surrounding cave formations, and metabolic functions may elucidate communal interactions between phyla and metabolic interactions with abiotic materials as shown in previous studies (Torres et al., 2009; Jones and Bennet, 2017). Next, a systematic study of the microbial communities collected in the cave via lab culturing will provide greater insight into the roles of these microbes in the cave ecosystem including determining the presence of carbon fixation, nitrogen fixation, or dissimilatory metal reduction/oxidation.

In addition, the cave is currently undergoing active exploration and since collecting samples for this study, new passages containing large multicolored speleosol deposits have been discovered, with a breakthrough in 2017 contributing to a $\sim 5$ expansion in the size of the cave. The location of this discovery can be seen in Figure 1, southeast of Disappointment Dome, where the map is labelled too tight. As uncharted areas of the cave continue to be unveiled, analyzing the microbial communities inhabiting these pristine locations may lead to discoveries of novel microorganisms (Jurado et al., 2006, 2007; Bonis and Gralnik, 2015; Hamm et al., 2017) or further elucidate the role of microorganisms in the biogeochemistry of cave and karst systems (Kappler et al., 2005). The presence of microbes previously associated with the production of antifungals for WNS (Hamm et al., 2017) and the development of next generation biofuels (Bond and Lovley, 2002; Rittmann, 2008) and biotechnology (Zhou et al., 2016; Lusk et al., 2018b) also emphasizes the importance of further research to evaluate these possibilities and continued exploration of dry sulfuric cave and karst systems.

Although there are no indications of the presence of non-microbial life in the cave, future studies should investigate the presence of eukaryotic life including invertebrates, yeasts, and other fungi. In addition, human traffic in rooms where samples were collected for this study, including Sugar Hill and below the ropes to Disappointment Dome, has increased so that visitors can observe the speleosols and sampling sites. A longitudinal study can be administered to assess the impact of human activities on the cave microbiome (Leuko et al., 2017) compared to pristine areas. Future investigations may elucidate how human activity indirectly impacts the development of cave and karst systems by influencing the resident microbial communities.

\section{ACKNOWLEDGEMENTS}

Juan Maldonado Ortiz (ASU Biological Design DNA sequencing), Misa Vening and David Lowry (SEM imaging), John McNuelty (owner of Grand Canyon Caverns), Chris Laurel (Goldwater Elemental Laboratory, ASU), Paul R. Jorgenson (images in Fig. 2), Benjamin Harrold for fossil guidance, Troy Hayden for highlighting this research on the local news, the Central Arizona Grotto, the ASU Outdoors Club, and everyone who donated to Science the Earth to support the mission of Lusk $2019 \mathrm{~b}$ to encourage democracy in the narrative of science. 


\section{REFERENCES}

Angert, E., Northup, D., Reysenbach, A., and Peek, A., 1998, Molecular phylogenetic analysis of a bacterial community in Sulphur River, Parker Cave, Kentucky: The American Mineralogist, v. 83, no. 11-12, p. 1583-1592, https://doi.org/10.2138/am-1998-1119.

Bae, H., Morrison, E., Chanton, J., and Ogram, A., 2018, Methanogens are major contributors to nitrogen fixation in soils of the Florida Everglades: Applied and Environmental Microbiology, v. 84, no. 7, p. 1-16, https://doi.org/10.1128/AEM.02222-17.

Barka, E., Vatsa, P., Sanchez, L., Gaveau-Vaillant, N., Jacquard, C., Meier-Kolthoff, J., Jan P., Klenk, H., Clément, C., Ouhdouch, Y., and Van Wezel, G., 2016, Taxonomy, physiology, and Natural products of Actinobacteria: Microbiology and Molecular Biology Reviews: MMBR, v. 80, no. 1, p. 1-43, https://doi.org/10.1128/MMBR.00019-15.

Barton, H., Giarrizzo, J., Suarez, P., Robertson, C., Broering, M., Banks, E., Vaishampayan, P.A., and Venkateswaran, K., 2014, Microbial diversity in a Venezuelan orthoquartzite cave is dominated by the Chloroflexi (Class Ktedonobacterales) and Thaumarchaeota Group I.1c: Frontiers in Microbiology, v. 5, p. 615, https://doi.org/10.3389/fmicb.2014.00615.

Barton, H., and Northup, D.E., 2007, Geomicrobiology in cave environments: past, current and future perspectives: Journal of Cave and Karst Studies, v. 69, no. 1, p. 163-178.

Behrendt, L., Trampe, E.L., Nord, N.B., Nguyen, J., Kühl, M., Lonco, D., Nyarko, A., Dhinojwala, A., Hershey, O.S., and Barton, H., 2019, Life in the dark: Far-red absorbing cyanobacteria extend photic zones deep into terrestrial caves: Environmental Microbiology, v 22, no. 3, p. 952-963, https://doi.org/10.1111/1462-2920.14774

Bérdy, J., 2005, Bioactive microbial metabolites: The Journal of Antibiotics, v. 58, no. 1, p. 1-26.

Bijmans, M., De Vries, E., Yang, C., N. Buisman, C., Lens, P., and Dopson, M., 2010, Sulfate reduction at pH 4.0 for treatment of process and wastewaters: Biotechnology Progress, v. 26, no. 4, p. 1029-1037, https://doi.org/10.1002/btpr.400.

Blehert, D., Hicks, A., Behr, M., Meteyer, C., Berlowski-Zier, B., Buckles, E., Coleman, J.T.H., Darling, S.R., Gargas, A., Niver, R., Okoniewski, J.C., Rudd, R.J., and Stone, W., 2009, Bat white-nose syndrome: An emerging fungal pathogen?: Science, v. 323, no. 5911, p. 227, https://doi. org/10.1126/science.1163874.

Bond, D., and Lovley, D., 2003, Electricity production by Geobacter sulfurreducens attached to electrodes: Applied and Environmental Microbiology, v. 69 , no. 3, p. 1548-1555, https://doi.org/10.1128/AEM.69.3.1548-1555.2003.

Bonis, B., and Gralnick, J., 2015, Marinobacter subterrani, a genetically tractable neutrophilic Fe(II)-oxidizing strain isolated from the Soudan Iron Mine: Frontiers in Microbiology, v. 6, p. 719, https://doi.org/10.3389/fmicb.2015.00719.

Boston, P.J., Spilde, M.N., Northup, D.E., Curry, M.D., Melim, L.A., and Rosales-Lagarde, L., 2009, Microorganisms as speleogenetic agents: geochemical diversity but geomicrobial unity: Hypogene Speleogenesis and Karst Hydrogeology of Artesian Basins, v. 1, p. 51-58.

Bolyen E, Rideout JR, Dillon MR, Bokulich NA, Abnet CC, AI-Ghalith GA, et al., 2019, Reproducible, interactive, scalable and extensible microbiome data science using QIIME 2: Nature Biotechnology, v. 37, p. 852-857, https://doi.org/10.1038/s41587-019-0209-9.

Bull, A. T., and Asenjo, J. A., 2013, Microbiology of hyper-arid environments: recent insights from the Atacama Desert, Chile: Antonie Van Leeuwenhoek, v. 103, p. 1173-1179, https://doi.org/10.1007/s10482-013-9911-7.

Caporaso, J. G., Lauber C.L., Walters, W.A., Berg-Lyons, D., Huntley, J., Fierer, N., Owens, S.M., Betley, J., Fraser, L., Bauer, M., Gormley, N., Gilbert, J.A., Smith, G., and Knight, R., 2012, Ultra-high-throughput microbial community analysis on the Illumina HiSeq and MiSeq platforms: The ISME Journal, v. 6, no. 8, p. 1621-1624, https://doi.org/10.1038/ismej.2012.8.

Caspi, R., Tebo, B.M., and Haygood, M.G, 1998, C-Type cytochromes and manganese oxidation in Pseudomonas putida MnB1: Applied and Environmental Microbiology, v. 64, no. 10, p. 3549-3555.

Chen, J., Toth, J., and Kasap, M., 2001, Nitrogen-fixation genes and nitrogenase activity in Clostridium acetobutylicum and Clostridium beijerinckii: Journal of Industrial Microbiology and Biotechnology, v. 27, no. 5, p. 281-286. https://doi.org/10.1038/sj.jim.7000083.

Coates, J.D., Ellis, D.J., Gaw, C.V., and Lovley, D.R. (1999). Geothrix fermentans gen. nov., sp. nov., a novel Fe(III)-reducing bacterium from a hydrocarbon-contaminated aquifer: International Journal of Systematic and Evolutionary Microbiology. v. 49, no. 4, p. 1615-22, https://doi. org/10.1099/00207713-49-4-1615.

Cunningham, K.I., Northup, D.E., Pollastro, R.M., Wright, W.G., and LaRock, E.J., 1995, Bacteria, fungi and biokarst in Lechuguilla Cave, Carlsbad Caverns National Park, New Mexico: Environmental Geology, v. 25, p. 2, https://doi.org/10.1007/BF01061824.

Denayer, J., Poty, E., Marion, J., and Mottequin, B., 2012, Lower and Middle Famennian (Upper Devonian) rugose corals from southern Belgium and northern France: Geologica Belgica, v. 15, no. 4, p. 273-283.

Dhami, N., Mukherjee, A., and Watkin, E., 2018, Microbial diversity and mineralogical-mechanical properties of calcitic cave speleothems and biomineralization conditions: Frontiers in Microbiology, v. 9, p. 40, https://doi.org/ 10.3389/fmicb.2018.00040.

Diaz-Herraiz, M., Jurado, V., Cuezva, S., Laiz, L., Pallecchi, P., Tiano, P., Sanchez-Moral, S., and Saiz-Jimenez, C., 2014, Deterioration of an Etruscan tomb by bacteria from the order Rhizobiales: Scientific Reports, v. 4, no. 1, p. 3610, https://doi.org/10.1038/srep03610.

Eddie, B., Wang, Z., Malanoski, A., Hall, R., Oh, S., Heiner, C., Lin, B., and Strycharz-Glaven, S., 2016, 'Candidatus tenderia electrophaga', an uncultivated electroautotroph from a biocathode enrichment: International Journal of Systematic and Evolutionary Microbiology, v. 66, no. 6, p 2178-2185, https://doi.org/10.1099/ijsem.0.001006.

Edgar, R.C., Haas, B.J., Clemente, J.C., Quince, C., Knight, R., 2011, UCHIME improves sensitivity and speed of chimera detection: Bioinformatics, v. 27, no. 16, p. 2194-2200, https://doi.org/10.1093/bioinformatics/btr381.

El-Naggar, M.Y., Wanger, G., Leung, K.M., Yuzvinsky, T.D., Southam, G., Yang, J., Lau, W.N., Nealson, K.H., and Gorby, Y.A., 2010, Electrical transport along bacterial nanowires from Shewanella oneidensis MR-1: Proceedings of the National Academy of Sciences, v. 107, no. 42, p. 18127-18131, https://doi.org/10.1073/pnas.1004880107.

Emerson, D., Moyer, C., 1997, Isolation and characterization of novel iron-oxidizing bacteria that grow at circumneutral pH: Applied and Environmental Microbiology, v. 63, no. 12, p. 4784-4792, https://doi.org/10.1128/AEM.63.12.4784-4792.1997.

Engel, A., Stern, L., Bennett, P., 2004, Microbial contributions to cave formation: New insights into sulfuric acid speleogenesis: Geology, v. 32 , no. 5, p. 369-372, https://doi.org/10.1130/G20288.1.

Forbes, J., 1998, Air temperature and relative humidity study: Torgac Cave, New Mexico: Journal of Cave and Karst Studies, v. 60, no. 1, p. 27-32.

Erlich, H.L., 1980, Different forms of microbial manganese oxidation and reduction and their environmental significance: in Trudinger, P.A., Walter, M.R., Ralph, B.J., eds., Biogeochemistry of Ancient and Modern Environments. Springer, Berlin, Heidelberg, p. 327-332.

Gaidos, E., Marteinsson, V., Thorsteinsson, T., Jóhannesson, T., Rúnarsson, A.R., Stefansson, A., Glazer, B., Lanoil, B., Skidmore, M., Han, S., Miller, M., Rusch, A., and Foo, W., 2008, An oligarchic microbial assemblage in the anoxic bottom waters of a volcanic subglacial lake: The ISME Journal, v. 3, no. 4, p. 486-497, https://doi.org/ 10.1038/ismej.2008.124. 
Gao, L., Lu, X., Liu, H., Li, J., Li, W., Song, R., Wang, R., Zhang, D., and Zhu, J., 2019, Mediation of extracellular polymeric substances in microbial reduction of hematite by Shewanella oneidensis MR-1: Frontiers in Microbiology, v. 10, no. 575, p. 1-12, https://doi.org/10.3389/ fmicb.2019.00575

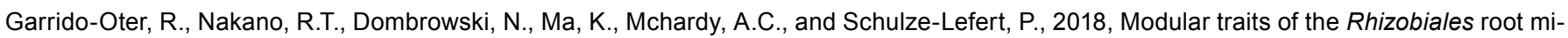
crobiota and their evolutionary relationship with symbiotic Rhizobia: Cell Host \& Microbe, v. 24, no. 1, p. 155-167.e5, https://doi.org/10.1016/j. chom.2018.06.006.

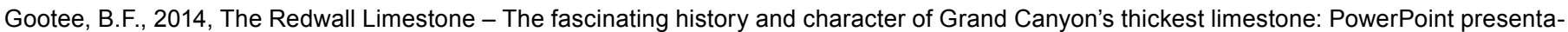
tion, Grand Canyon guide training seminar 8 February 2014, 1-27, Accessed online: http://repository.azgs.az.gov/sites/default/files/dlio/files/ nid1572/gootee_redwall_limestone_gts_2014.pdf

Gootee, B.F., 2019, Geological timeframe of the Grand Canyon: Arizona Geological Survey Open-File Report ORF-19-02, p. 1-2.

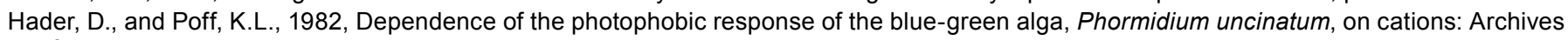
of Microbiology, v. 132, p. 345-348, https://doi.org/10.1007/BF00413387.

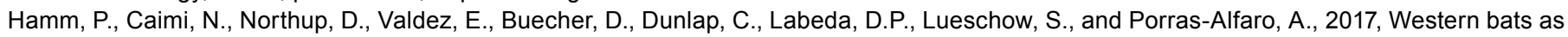
a reservoir of novel Streptomyces species with antifungal activity: Applied and Environmental Microbiology, v. 83, no. 5, p. 1-10, https://doi. org/10.1128/AEM.03057-16.

Hill, C.A., 1987, Geology of Carlsbad Cavern and other caves in the Guadalupe Mountains, New Mexico and Texas, Socorro: New Mexico Bureau of Mines and Mineral Resources, Bulletin 117.

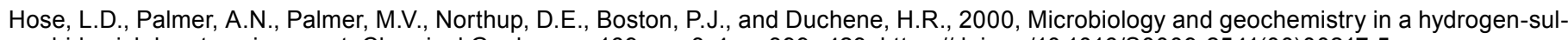
phide-rich karst environment: Chemical Geology, v. 169, no. 3-4, p. 399-423, https://doi.org/10.1016/S0009-2541(00)00217-5.

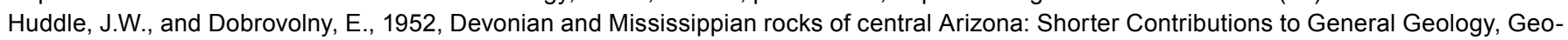
logical Survey Professional Paper 233-D. https://pubs.usgs.gov/pp/0233d/report.pdfHugerth L.W., Wefer H.A., Lundin S., Jakobsson H.E., Lindberg M., Rodin S., Engstrand L., Andersson A.F., 2014, DegePrime, a program for degenerate primer design for broad-taxonomic-range PCR in microbial ecology studies: Applied and Environmental Microbiology, v. 80, p. 5116-5123. https://doi.org/10.1128/AEM.01403-14.

Jones, A., and Bennett, P., 2017, Mineral Ecology: Surface Specific Colonization and Geochemical Drivers of Biofilm Accumulation, Composition, and Phylogeny: Frontiers in Microbiolog, v., 8, no. 491, p. 1-14, https://doi.org/10.3389/fmicb.2017.00491.

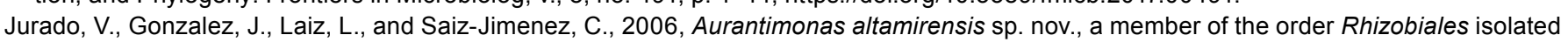
from Altamira Cave: International Journal of Systematic and Evolutionary Microbiology, v. 56, no. 11, p. 2583-2585, https://doi.org/10.1099/ ijs.0.64397-0.

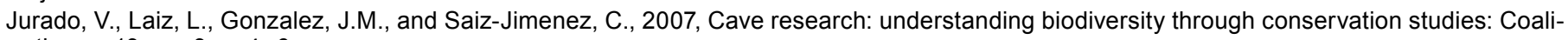
tion, v. 13, no. 3, p. 4-6.

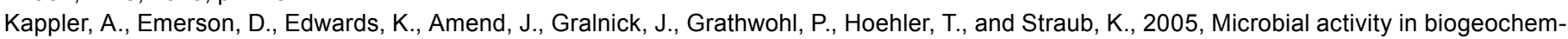
ical gradients - new aspects of research: Geobiology, v. 3, no. 3, p. 229-233, https://doi.org/10.1111/j.1472-4669.2005.00053.x.

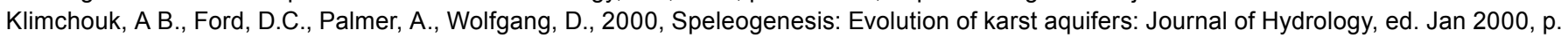
244-260, https://doi.org/10.1016/S0022-1694(00)00341-3

Kurapova, I., Zenova, G. M., Sudnitsyn, I. I., Kizilova, A. K., Manucharova, N. A., Norovsuren, Z. H., and Zvyagontsev, D.G., 2012, Thermotolerant and thermophilic Actinomycetes from soils of Mongolia Desert Steppe Zone: Microbiology, v. 81, p. 98-108, https://doi.org/10.1134/ S0026261712010092.

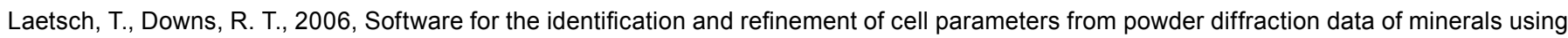
the RRUFF project and American Mineralogist Crystal Structure Databases: Abstracts from the $19^{\text {th }}$ general meeting of the International Mineralogical Association, Kobe, Japan, 23-28 July 2006. Accessed online: https://www.geo.arizona.edu/xtal/group/pdf/IMA19_P08-25.pdf

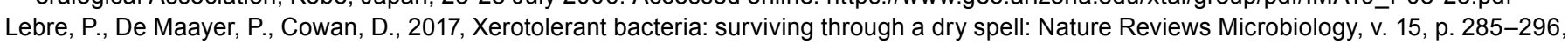
https://doi.org/10.1038/nrmicro.2017.16

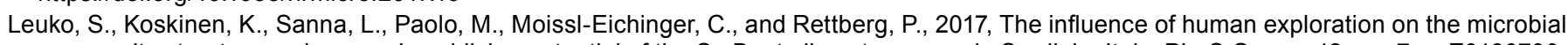
community structure and ammonia oxidizing potential of the Su Bentu limestone cave in Sardinia, Italy: PLoS One, v. 12, no. 7, p. E0180700, https://doi.org/10.1371/journal.pone.0180700.

Leigh, J.A., 2000, Nitrogen fixation in methanogens: the archaeal perspective: Current Issues in Molecular Biology, v. 2, no. 4, p. 125-131.

Lovley, D., 1993, Dissimilatory metal reduction: Annual Review of Microbiology, v. 47, no. 1, p. 263-290, https://doi.org/10.1146/annurev. mi.47.100193.001403.

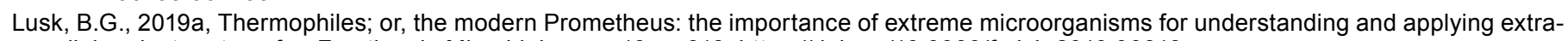
cellular electron transfer: Frontiers in Microbiology, v. 10, p. 818, https://doi.org/10.3389/fmicb.2019.00818.

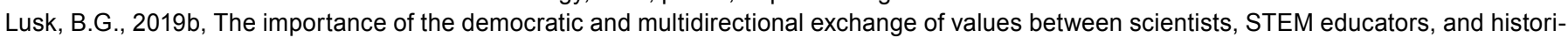
cally underrepresented members of the community: Journal of Responsible Innovation, v. 6, no. 2, p. 248-254, https://doi.org/10.1080/232994 60.2019.1571894.

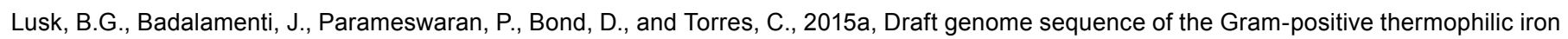
reducer Thermincola ferriacetica strain Z-0001T: Genome Announcements, v. 3, no. 5, p. 1-2, https://doi.org/10.1128/genomeA.01072-15.

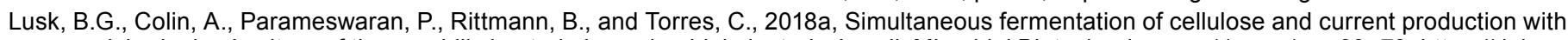
an enriched mixed culture of thermophilic bacteria in a microbial electrolysis cell: Microbial Biotechnology, v. 11, no. 1, p. 63-73, https://doi. org/10.1111/1751-7915.12733.

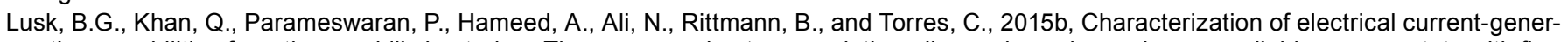
ation capabilities from thermophilic bacterium Thermoanaerobacter pseudethanolicus using xylose, glucose, cellobiose, or acetate with fixed anode potentials: Environmental Science \& Technology, v. 49, no. 24, p. 14725-14731, https://doi.org/10.1021/acs.est.5b04036.

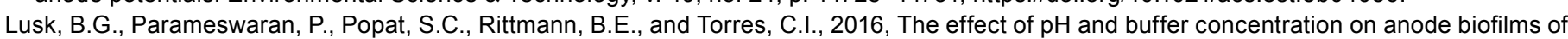
Thermincola ferriacetica, Bioelectrochemistry, v. 112, p. 47-52, https://doi.org/10.1016/j.bioelechem.2016.07.007.

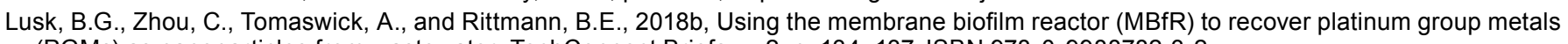
(PGMs) as nanoparticles from wastewater: TechConnect Briefs, v. 2, p. 134-137, ISBN 978-0-9988782-3-2.

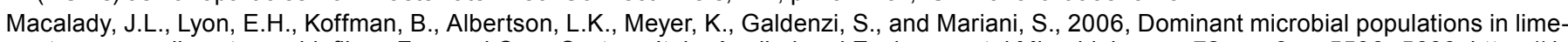
stone-corroding stream biofilms, Frasassi Cave System, Italy: Applied and Environmental Microbiology, v. 72, no. 8, p. 5596-5609, https://doi. org/10.1128/AEM.00715-06.

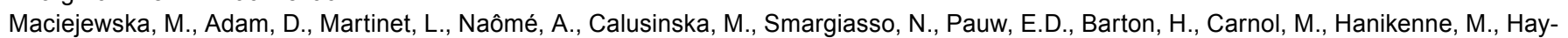
ette, M., Delpfosse, P., Baurain, D., Rigali, S., 2016, A phenotypic and genotypic analysis of the antimicrobial potential of cultivable Streptomyces isolated from cave moonmilk deposits: Frontiers in Microbiology, v. 7, p. 1-19, https://doi.org/10.3389/fmicb.2016.01455 
Mohammadipanah, F., and Wink, J., 2015, Actinobacteria from arid and desert habitats: diversity and biological activity: Frontiers in Microbiology, v. 6, p. 1541, https://doi.org/10.3389/fmicb.2015.01541.

Montero-Calasanz, M., Göker, M., Pötter, G., Rohde, M., Spröer, C., Schumann, P., Gorbushina A.A., Klenk H.P., 2012, Geodermatophilus arenarius sp. nov., a xerophilic actinomycete isolated from Saharan desert sand in Chad: Extremophiles, v. 16, p. 903-909, https://doi. org/10.1007/s00792-012-0486-4.

Montero-Calasanz, M. C., Göker, M., Pötter, G., Rohde, M., Spröer, C., Schumann, P., Gorbushina A.A., Klenk H.P., 2013, Geodermatophilus siccatus sp. nov., isolated from arid sand of the Saharan desert in Chad: Antonie Van Leeuwenhoek, v. 103, p. 449-456, https://doi.org/10.1007/ s10482-012-9824-x.

Montechiaro, F., and Giordano, M., 2006, Effect of prolonged dark incubation on pigments and photosynthesis of the cave-dwelling cyanobacterium Phormidium autumnale (Oscillatoriales, Cyanobacteria): Phycologia, v. 45, no. 6, p. 704-710, https://doi.org/10.2216/06-15.1.

Morris R.M., Rappé M.S., Connon S.A., Vergin K.L., Siebold W.A., Carlson C.A., Giovannoni S.J., 2002, SAR11 clade dominates ocean surface bacterioplankton communities: Nature, v. 420, p. 806-810, https://doi.org/10.1038/nature01240.

Nimaichand, S., Zhu, W., Yang, L., Ming, H., Nie, G., Tang, S., Ningthoujam, D., and Li, W., 2012, Streptomyces manipurensis sp. nov., a novel actinomycete isolated from a limestone deposit site in Manipur, India: Antonie Van Leeuwenhoek, v. 102, no. 1, p. 133-139, https://doi. org/10.1007/s10482-012-9720-4.

Northup, D., Barns, S., Yu, L., Spilde, M., Schelble, R., Dano, K., Crossey, L.J., Connolly, C.A., Boston, P.J., Natvig, D.O., and Dahm, C., 2003, Diverse microbial communities inhabiting ferromanganese deposits in Lechuguilla and Spider Caves: Environmental Microbiology, v. 5, no. 11, p. 1071-1086, https://doi.org/10.1046/j.1462-2920.2003.00500.x.

Northup, D. E., Melim, L.A., Spilde, M.N., Hathaway, JJM, Garcia, M.G., Moya, M., Stone, F.D., Boston, P.J., Dapkevicius, M.E.N.L., Riquelme, C., 2011, Lava cave microbial communities within mats and secondary mineral deposits: Implications for life detection on other planets: Astrobiology, v. 11, no. 7, p. 601-618, https://doi.org/ 10.1089/153110701750137413.

Parameswaran, P., Bry, T., Popat, S., Lusk, B., Rittmann, B., and Torres, C., 2013, Kinetic, electrochemical, and microscopic characterization of the thermophilic, anode-respiring bacterium Thermincola ferriacetica: Environmental Science \& Technology, v. 47, no. 9, p. 4934-4940, https://doi.org/10.1021/es400321c.

Pedregosa, F., Varoquaux, G., Gramfort, A., Michel, V., Thirion, B., Grisel, O., Blondel, M., Müller, A., Nothman, J., Louppe, G., Prettenhofer, P., Weiss, R., Dubourg, V., Vanderplas, J., Passos, A., Cournapeau, D., Brucher, M., Perrot, M., Duchesnay, E., 2018, Scikit-learn: Machine Learning in Python; Journal of Machine Learning Research, arXiv:1201.0490v4 [cs.LG].

Murray, P.M. and Zinder, S.H., 1984, Nitrogen fixation by a methanogenic archaebacterium: Nature, v. 312, no. 5991, p. 284-286, https://doi. org/10.1038/312284a0.

Myers, C., and Nealson, K., 1988, Bacterial manganese reduction and growth with manganese oxide as the sole electron acceptor: Science, v. 240, no. 4857, p. 1319-1321, https://doi.org/10.1126/science.240.4857.1319.

Payne, R.B., Gentry, D.M., Rapp-Giles, B.J., Casalot, L., and Wall, J.D., 2002, Uranium reduction by Desulfovibrio desulfuricans strain G20 and a cytochrome c3 mutant: Applied and Environmental Microbiology, v. 68, no. 6, p. 3129-3132, https://doi.org/10.1128/aem.68.6.31293132.2002.

Pedder, A., and Murphy, M., 2004, Emsian (Lower Devonian) rugosa of Nevada: revision Of systematics and stratigraphic ranges, and reassessment of faunal provincialism: Journal of Paleontology, v. 78, no. 5, p. 838-865, https://doi.org/10.1666/0022-3360(2004)078<0838:ELDRON>2.0.CO;2.

Pfeffer, C., Larsen, S., Song, J., Dong, M., Basenbacher, F., Meyer, R.L., Kjekdsen, K.U., Schreiber, L., Gorby, Y.A., El-Naggar, M.Y., Leung, K.M., Schramm, A., Risgaard-Petersen, N., and Nielsen, L.P., 2012, Filamentous bacteria transport electrons over centimetre distances: Nature, v. 491, no. 7423 , p. 218-221, https://doi.org/10.1038/nature11586.

Price, L.G., 1999, Geology of the Grand Canyon. Grand Canyon, Arizona: Grand Canyon Association, 64 p.

Provencio, P., Victor J., and Polyak, P., 2001, Iron oxide-rich filaments: possible fossil bacteria in Lechuguilla Cave, New Mexico: Geomicrobiology Journal, v. 18, no. 3, p. 297-309, https://doi.org/10.1080/01490450152467804.

Quast, C., Pruesse, E., Yilmaz, P., Gerken, J., Schweer, T., Yarza, P., Peplies, G., Glöckner, F., 2013, The SILVA ribosomal RNA gene database project: Improved data processing and web-based tools: Nucleic Acids Research, v. 41, no. D1, D590-D596, https://doi.org/10.1093/nar/ gks1219.

Ramos, J.L., 2003, Lessons from the genome of a lithoautotroph: making biomass from almost nothing: Journal of Bacteriology, v. 185, no. 9, p. 2690-2691, https://doi.org/10.1128/jb.185.9.2690-2691.2003.

Rangseekaew, P., and Pathom-Aree, W., 2019, Cave Actinobacteria as producers of bioactive metabolites: Frontiers in Microbiology, v. 10, p. 387, https://doi.org/10.3389/fmicb.2019.00387.

Rideout, J., He, Y., Navas-Molina, J., Walters, W., Ursell, L., Gibbons, S., Chase, J., Mcdonald, D., Gonzalez, A., Robbins-Pianka, A., Clemente, J., Gilbert, J., Huse, S., Zhou, H., Knight, R., Caporaso, J., and Argonne National Lab, 2014, Subsampled open-reference clustering creates consistent, comprehensive OTU definitions and scales to billions of sequences: PeerJ 2, no. E545, https://doi.org/10.7717/peerj.545.

Rittmann, B., 2008, Opportunities for renewable bioenergy using microorganisms: Biotechnology and Bioengineering, v. 100, no. 2, p. 203-212, https://doi.org/10.1002/bit.21875.

Roden, E., Lovley, D., 1993, Dissimilatory Fe(III) reduction by the marine microorganism Desulfuromonas acetoxidans: Applied and Environmental Microbiology, v. 59, no. 3, p. 734-742, https://doi.org/10.1128/AEM.59.3.734-742.1993.

Rosenblueth, M., Ormeño-Orrillo, E., López-López, A., Rogel, M.A., Reyes-Hernández, B.J., Martínez-Romero, J.C., Reddy, P.M., and Martínez-Romero, E., 2018, Nitrogen fixation in cereals: Frontiers in Microbiology, v. 9, p. 1794, https://doi.org/10.3389/fmicb.2018.01794.

Santi, C., Bogusz, D., and Franche, C., 2013, Biological nitrogen fixation in non-legume plants: Annals of Botany, v. 111, no. 5, p. 743-767, https:// doi.org/10.1093/aob/mct048.

Sen, R., Ishak, H.D., Estrada, D., Dowd, S.E., Hong, E., and Mueller, U.G., 2009, Generalized antifungal activity and 454-screening of Pseudonocardia and Amycolatopsis bacteria in nests of fungus-growing ants: Proceedings of the National Academies of Sciences, v. 106, no. 42, p. 17805-17810, https://doi.org/10.1073/pnas.0904827106.

Snoeyink, V.L., and Jenkins, D., 1980, Water Chemistry. John Wiley \& Sons, p. 380-381, ISBN 0-471-05196-9.

Spilde, M.N., Kooser, A., Boston, P.J., and Northup, D.E., 2009, Speleosol: a subterranean soil: Minerology, Proceedings of the $15^{\text {th }}$ International Conference of Speleology, p. 338-334.

Spilde, M.N., Northup, D.E., Boston, P.J., Schelble, R.T., Dano, K.E., Crossey, L.J., 2005, Geomicrobiology of cave ferromanganese deposits: a field and laboratory investigation: Geomicrobiology Journal, v. 22, p. 99-116, https://doi.org/10.1080/01490450590945889. 
Spilde, M.N., Northup, D.E., Boston, P.J., 2006, Ferromanganese deposits in the caves of the Guadalupe Mountains: New Mexico Geological Society guidebook, $57^{\text {th }}$ conference, Caves and Karst of Southeast New Mexico, p. 161-166.

Sun, Y., Tang, H., Ribbe, A., Duzhko, V., Woodard, T., Ward, J., Joy, E., Bai, Y., Nevin, K.P., Nonnenmann, S.S., Russell, T., Emrick, T., and Lovley, D., 2018, Conductive composite materials fabricated from microbially produced protein nanowires: Small, v. 14, no. 44, p. 1-5, https://doi. org/10.1002/smll.201802624.

Také, A., Inahashi, Y., Ōmura, S., Takahashi, Y., \& Matsumoto, A., 2018, Streptomyces boninensis sp. nov., isolated from soil from a limestone cave in the Ogasawara Islands: International Journal of Systematic and Evolutionary Microbiology, v. 68, no. 5, p. 1795-1799. https://doi. org/10.1099/ijsem.0.002753.

Tisato, N., Torriani, S.F.F., Monteux, S., Sauro, F., Waele, J.D., Tavagna, M.L., D’Angeli, I.M., Chailloux, D., Renda, M., Eglinton, T.I., and Bontognali, T.R.R., 2015, Microbial mediation of complex subterranean mineral structures: Scientific Reports, v. 5, no. 1, p. 15525, https://doi. org/10.1038/srep15525.

Torres, C., Krajmalnik-Brown, R., Parameswaran, P., Marucs, A., Wanger, G., Gorby, Y., Rittmann, B., 2009, Selecting Anode-Respiring Bacteria Based on Anode Potential: Phylogenetic, Electrochemical, and Microscopic Characterization: Environmental Science and Technology, v. 43, p. 9519-9524, https://doi.org/10.1021/es902165y.

Wagner, S. C., 2011, Biological nitrogen fixation: Nature Education Knowledge, v. 3, no. 10, p. 15.

Wang, F., Gu, Y., O'brien, J.P., Yi, S.M., Yalcin, S.E., Srikanth, V., Shen, C., Vu, D., Ing, N.L., Hochbaum, A.I., Egelman, E.H., and Malvankar, N.S., 2019, Structure of microbial nanowires reveals stacked hemes that transport electrons over micrometers: Cell, v. 177, no. 2, p. $361-369$. e10, https://doi.org/10.1016/j.cell.2019.03.029.

Wang, X., Schröder, H.C., Wiens, M., Schloßmacher, U., and Müller, W.E.G., 2009, Manganese/polymetallic nodules: micro-structural characterization of exolithobiontic- and endolithobiontic microbial biofilms by scanning electron microscopy: Micron, v. 40, no. 3, p. 350-358, https://doi. org/10.1016/j.micron.2008.10.005.

Weber, K.A., Achenbach, L.A., and Coates, J.D., 2006, Microorganisms pumping iron: anaerobic microbial iron oxidation and reduction: Nature Reviews Microbiology, v. 4, no. 10, p. 752-764, https://doi.org/10.1038/nrmicro1490.

Wierzchos, J., Cámara, B., De Los Ríos, A., Davila, A.F., Sánchez Almazo, I.M., Artieda, O, Wierzchos, K., Gomez-Silva, B., Mckay, C., and Ascaso, C., 2011, Microbial colonization of Ca-sulfate crusts in the hyperarid core of the Atacama Desert: implications for the search for life on Mars: Geobiology, v. 9, no. 1, p. $44-60$, https://doi.org/10.1111/j.1472-4669.2010.00254.x.

Wirsen, C. O., Sievert, S. M., Cavanaugh, C. M., Molyneaux, S. J., Ahmad, A., Taylor, L. T., Delong, E.F., and Taylor, C. D., 2002, Characterization of an autotrophic sulfide-oxidizing marine Arcobacter sp. that produces filamentous sulfur: Applied and Environmental Microbiology, v. 68, no. 1, p. 316-325, https://doi.org/10.1128/aem.68.1.316-325.2002.

Zhang, F., Lin, C., Bian, L., Glasby, G.P., and Zhamoida, V.A., 2002, Possible evidence for the biogenic formation of spheroidal ferromanganese concretions from the eastern Gulf of Finland, the Baltic Sea: Baltica, v. 15, p. 23-29.

Zhou, C., Ontiveros-Valencia, A., Wang, Z., Maldonado, J., Zhao, H., Krajmalnik-Brown, R., and Rittmann, B., 2016, Palladium recovery in a H ${ }_{2}^{-}$ based membrane biofilm reactor: formation of $\mathrm{Pd}(0)$ nanoparticles through enzymatic and autocatalytic reductions: Environmental Science \& Technology, v. 50, no. 5, p. 2546 -2555, https://doi.org/10.1021/acs.est.5b05318. 